все положения и особенности относительно реализации конституционных прав на квалифицированную юридическую помощь в Российской Федерации.

$$
* * *
$$

1. Конституция РФ, принятая всенародным голосованием 12 декабря 1993 г. // Российская газета. 1993. - № 237;

2. Уголовно-процессуальный кодекс Российской Федерации от 18 декабря 2001 г. № 174-Ф3 // Парламентская газета. - 2001. - № 241-242;

3. Гражданский процессуальный кодекс Российской Федерации от 14 ноября 2002 № 138-Ф3 // Собрание законодательства РФ. - 2002. - № 46. - ст. 4532.

4. Федеральный закон от 21 ноября 2011 г. «О бесплатной юридической помощи в Российской Федерации» // Российская газета. - 2011. - № 263;

5. Грудцына Л.Ю. Адвокатское право: Учебно-практическое пособие / М.: Деловой двор. 2009 - 352 c.;

6. Юрьев С.С. Адвокатура России: Учебник для магистров / М.: Юрайт. 2013. - 798 с.

\title{
Харитонова А.Д. \\ Конституционно-правовой механизм, позволяющий не исполнять решения ЕСПЧ, как ограничение права на защиту в межгосударственном органе
}

\author{
Дальневосточный федеральный университет
}

(Россия, Владивосток)

doi:10.18411/spc-20-12-2017-10

idsp: 000001:spc-20-12-2017-10

Конституцией Российской Федерации (далее по тексу - Конституция РФ) в ч. 3 ст. 46 определено, что каждый вправе обращаться в межгосударственные органы по защите прав и свобод человека и гражданина, когда исчерпаны все имеющиеся внутригосударственные средства правовой защиты. Российская Федерация (далее по тексту - РФ) признала юрисдикцию Европейского суда по правам человека (далее ЕСПЧ), ратифицировав Европейскую конвенцию о защите прав человека и основных свобод 1950 года (далее по тексту - Конвенция). Конвенция приобрела силу на территории нашей страны 5 мая 1998 г., таким образом, ЕСПЧ стал основным межгосударственным органом по защите прав и свобод человека и гражданина для России, и решения ЕСПЧ стали обязательными для исполнения.

Статья 46 Конвенции на Высокие Договаривающиеся Стороны обязательство исполнять окончательные постановления ЕСПЧ по любому делу, в котором они выступают сторонами (п. 1), и тем самым с исчерпывающей ясностью наделяющей все без исключения такие постановления свойством resjudicata. В совокупности с фундаментальным общеправовым принципом pactasuntservanda, закрепленным в ст. 26 Венской конвенции о праве международных договоров 1969 г., участницей которой является и РФ, это, казалось бы, исключает даже малейшие колебания на счет обязательности решений Страсбургского суда.

Однако с 2015 года вопрос исполнения постановлений ЕСПЧ в России обострился после принятия 14 июля 2015 года Конституционным Судом РФ (далее по тексту - КС РФ) постановления N 21-П, в котором была признана возможность неисполнения постановлений Европейского суда.

Впоследствии был принят Федеральный конституционный закон от 14.12.2015 N 7-ФКЗ «О внесении изменений в Федеральный конституционный закон «О Конституционном Суде Российской Федерации», в соответствии с которым КС РФ получил право выносить постановления о невозможности исполнения в целом или в части решения межгосударственного органа по защите прав и свобод человека, 
принятого на основании положений международного договора РФ в их истолковании межгосударственным органом по защите прав и свобод человека, в связи с которым был подан запрос в КС РФ. Таким образом, у России появился конституционноправовой механизм (далее по тексту - механизм), позволяющей не исполнять решения ЕСПЧ.

Так, в случае если - КС РФ принимает постановление о невозможности исполнения решения межгосударственного органа по защите прав и свобод человека (ЕСПЧ), то какие-либо действия (акты), направленные на исполнение соответствующего решения межгосударственного органа по защите прав и свобод человека, в РФ не могут осуществляться (приниматься).

Рассуждая о данном механизме, следует мысль что, государство, установив данный конституционный механизм, ограничивает право на защиту в межгосударственном органе по защите прав и свобод - ЕСПЧ. Право на защиту в межгосударственном органе, также включает в себя права (материальные - получение денежной компенсации; процессуальные -пересмотр судебного решения по вновь открывшимся обстоятельствам), вытекающие в случае выявления нарушений норм Конвенции, из решения межгосударственного органа. Например, если ЕСПЧ выявил нарушение права, в своем постановлении ЕСПЧ обязывает государство, против которого принято декларативное постановление о нарушении прав человека, не только выплатить определенную компенсацию, но и принять соответствующие меры индивидуального характера по отношению к потерпевшему, чтобы «положить конец нарушению и устранить его последствия с целью восстановления, насколько это возможно, ситуации, существовавшей до нарушения».Однако, теперь получается, что все, сопутствующие основному праву - возможность обращаться в межгосударственные органы за защитой права, права, возникающие в ходе реализации вышеуказанного права, могут быть по решению КС РФ не исполнены, если суд сочтет неисполнимым решение ЕСПЧ. Таким образом, не исключая права обращения за защитой в межгосударственные органы в целом, с помощью работы нового конституционно-правового механизма, возможны ограничения данного права. Естественно такие изменения имеют и политический характер, в ответ на политизированность деятельности ЕСПЧ, по мнению некоторых государственных деятелей.

Уже во втором деле, в котором КС РФ были реализованы предоставленные ему полномочия, стало разрешение вопроса о возможности исполнения в соответствии с Конституцией РФ, постановления ЕСПЧ от 31 июля 2014 г. по делу «ОАО « Нефтяная компания «ЮКОС» против России», в части выплаты присужденной материальной денежной компенсации, в связи с запросом Министерства юстиции РФ.Постановлением КС РФ от 19 января 2017 г. N 1-П исполнение Постановления ЕСПЧ от 31 июля 2014 г. по делу по делу «ОАО «Нефтяная компания «ЮКОС» против России» в части выплаты денежной компенсации признано невозможным, поскольку выплата присужденной ЕСПЧ бывшим акционерам компании, выстроившей незаконные схемы уклонения от налогообложения, их наследникам и правопреемникам столь значительной денежной компенсации из той бюджетной системы, которая регулярно не получала от нее в должном объеме огромные суммы налоговых платежей, необходимые в том числе для выполнения публичных обязательств перед всеми гражданами, преодоления финансового и экономического кризиса, противоречит конституционным принципам равенства и справедливости в налоговых 
правоотношениях (статья 17, часть 3 ; статья 19, части 1 и 2; статья 55, части 2 и 3;статья 57 Конституции Российской Федерации). В данном случае наглядно продемонстрировано использование конституционно-правового механизма, как законного способа государства не исполнять невыгодное государству решение ЕСПЧ, ограничив при этом сущность межгосударственной защиты.

КС РФ, вынося от 14 июля 2015 года КС РФ Постановление N 21-П, которое предопределило создание конституционно-правового механизма, о котором идет речь, назвал цели введения нового механизма, позволяющего не исполнять решения ЕСПЧ, сформировав свою позицию следующим образом: «Применительно к российским конституционным реалиям ни Европейская конвенция сама по себе, ни тем более основанные на истолковании содержащихся в ней положений постановления ЕСПЧ не выведены из-под действия Конституции, а потому их имплементация в российский правопорядок возможна лишь на условиях признания суверенитета Российской Федерации (ст. 4, ч. 1), высшей юридической силы Конституции РФ (ст. 15, ч. 1) и недопустимости участия России в международных договорах, если такое участие влечет ограничение прав и свобод человека и гражданина и противоречит основам конституционного строя России (ст. 79). Будучи связанной требованием соблюдать международный договор, каковым является Конвенция о защите прав человека и основных свобод, Российская Федерация, тем не менее, обязана обеспечивать в рамках своей правовой системы верховенство Конституции, что вынуждает ее в случае возникновения коллизий между ними - притом, что Конституция РФ и Европейская конвенция основаны на одних и тех же базовых ценностях защиты прав и свобод человека и гражданина - отдавать предпочтение конституционным предписаниям и тем самым не следовать буквально постановлению ЕСПЧ, когда его реализация противоречит конституционным ценностям». Таким образом, государство в лице КС РФ, вводя новый механизм, в случае работы которого, ограничивает право на защиту в межгосударственном органе, в качестве легитимных целей указывает на необходимость сохранности суверенитета, основ конституционного строя и высшей юридической силы Конституции РФ.

В этом же постановлении от 14 июля 2015 года № 21-П, КС РФ указывает на необходимость введения механизма, который ограничивает право, на международную защиту, указывая следующие доводы: «В ситуации, когда самим содержанием постановления ЕСПЧ, в том числе в части обращенных к государству-ответчику предписаний, основанных на положениях Конвенции, интерпретированных ЕСПЧ в рамках конкретного дела, неправомерно - с конституционно-правовой точки зрения затрагиваются принципы и нормы Конституции РФ, Россия может в порядке исключения отступить от выполнения возлагаемых на нее обязательств, когда такое отступление является единственно возможным способом избежать нарушения основополагающих принципов и норм Конституции РФ». Такой трактовкой, суд показывает, что введение и работа конституционно-правового механизма необходимо, чтобы не нарушить верховенство Конституции РФ.

С точки зрения баланса между установленным механизмом, который мы рассматриваем как ограничение права на международную защиту и целями, которые при этом преследовало государство, КС РФ свою позицию излагает следующим образом: «Безусловное исполнение Россией решений межгосударственного органа, принятых на основании международного договора в не согласующемся с Конституцией РФ истолковании, могло бы повлечь нарушение ее положений.При этом, речь в таких 
случаях идет не о действительности или недействительности для России международного договора в целом, а лишь о невозможности соблюдения обязательства о применении его нормы в истолковании, приданном ей уполномоченным межгосударственным органом в рамках рассмотрения конкретного дела». Здесь КС РФ говорит, что недопустимо нарушение положений Конституции РФ, указывая также в своей позиции, что вводя механизм, Россия не отказывается фактически от взятого на себя обязательства по Конвенции, однако, в части толкования межгосударственного органа имеет право не согласиться с решением. Также КС РФ отмечает: «КС РФ не может поддержать данное ЕСПЧ толкование Конвенции, если именно Конституция РФ (в том числе в ее истолковании КС РФ) как правовой акт, обладающий высшей юридической силой в правовой системе России, более полно по сравнению с соответствующими положениями Конвенции в их истолковании ЕСПЧ обеспечивает защиту прав и свобод человека и гражданина, в том числе в балансе с правами и свободами иных лиц.В то же время, признавая фундаментальное значение европейской системы защиты прав и свобод человека и гражданина, частью которой является постановление ЕСПЧ, КС РФ готов к поиску правомерного компромисса ради поддержания этой системы, но определение степени своей готовности он оставляет за собой, поскольку границы компромисса в данном вопросе очерчивает именно Конституция РФ». КС РФ демонстрирует, что механизм, и связанные с ним ограничения, соразмерны целям защиты прав человека и гражданина на основе признания верховенства Конституции РФ.

В Постановлении КС РФ от 19 апреля 2016 г. N 12-Пуказывает: «Из приведенной правовой позиции, изложенной в Постановлении КС РФ от 14 июля 2015 года N 21-П, следует, что КС РФ как последняя инстанция по разрешению в рамках действующего конституционного регулирования вопроса о возможности исполнения постановлений ЕСПЧ как межгосударственного органа по защите прав и свобод человека должен в соответствии с международными обязательствами России находить при осуществлении данного полномочия разумный баланс, с тем чтобы принятое им решение, с одной стороны, отвечало бы букве и духу постановления Европейского Суда по правам человека, а с другой - не вступало бы в противоречие с основами конституционного строя РФ и установленным Конституцией РФ правовым регулированием прав и свобод человека и гражданина». Таким образом, орган конституционного контроля пытается показать благую цель своих действий, что КС РФ применяя новый механизм, намерен учитывать позицию ЕСПЧ насколько это возможно, и делает акцент на основах конституционного строя.

Основными целями механизма являются сохранность суверенитета, обеспечение высшей силы Конституции РФ. Однако, если проанализировать текущую практику ЕСПЧ, становится очевидным, что она не касается вопросов национального суверенитета, в связи с этим представляется, что логика рассуждений КС РФ как некое оправдание своей относимости к рассматриваемому основному вопросу - введение ограничений исполнимости решений ЕСПЧ в России, вызванных фактически политическими и экономическими причинами.

Весьма интересно в этой связи заключение Венецианской комиссии от 11.03.2016, касаемо нового механизма КС РФ, которая является экспертноконсультативным органом Совета Европы по конституционному праву. Ею определено, что полученное КС РФ право выносить постановления о «невозможности исполнения» международных решений, включая постановления ЕСПЧ, несовместимо с 
международно-правовыми обязательствами России. Наделение такими полномочиями может препятствовать в той или иной мере исполнению международных решений в Российской Федерации, следовательно, в Закон о КС РФ должны быть внесены соответствующие изменения. По мнению экспертов Венецианской комиссии, неспособность КС РФ устранить противоречия между Конституцией РФ и международными решениями не освобождает государство от обязанности исполнять международные решения. Обязанностью всех государственных органов является приведение в соответствие положений международных договоров, действующих в России, Конституции РФ, в том числе путем толкования или же внесения изменений в Конституцию РФ.

Венецианская комиссия подчеркнула, что «Российской Федерации необходимо использовать диалог, а не односторонние меры», добавив, что в нескольких государствах Совета Европы диалог был эффективным инструментом устранения противоречий, возникающих между постановлениями ЕСПЧ и национальными правовыми системами.

В связи с этим она рекомендовала Российской Федерации предпринять ряд шагов:- «возможность исполнения решения» заменить на «совместимость с Конституцией Российской Федерации средства исполнения международного решения»; - удалить статьи, согласно которым не могут осуществляться какие-либо действия, направленные на исполнение международного решения, объявленного КС РФ не соответствующим Конституции РФ; - законодательно указать на обязанность российских властей находить альтернативные способы исполнения международного решения; - определить в законе, что меры индивидуального характера, излагаемые в постановлениях ЕСПЧ, как, например, выплата справедливой компенсации, не могут быть предметом оценки конституционности; - разрабатывать любые процедуры, подразумевающие оценку возможности исполнения, таким образом, чтобы они обязательно предусматривали участие лица, выступавшего заявителем в соответствующем международном суде или органе.

Между тем заключения Венецианской комиссии носят рекомендательный характер и не предусматривают принудительных форм исполнения. При игнорировании таких полномочий государство несет фактически лишь репутационные издержки, влияющие на его имидж. Таким образом, очевидна негативная реакция Совета Европы на новые возможности России касаемо деятельности ЕСПЧ.

Стоит заметить, что в своих постановлениях, КС РФ указывает позицию, согласно которой, не отрицает поиска взаимоприемлемых средств достижения разумного компромисса с ЕСПЧ, позволяющего избегать конфликтов между внутригосударственным и международным правовым регулированием, тем не менее, в отношении исполнения постановлений Суда, КС РФ говорит, что постановления ЕСПЧ не могут иметь безусловного приоритета перед конституционными нормами, а потому их реализация требует взвешенного и весьма осторожного сопряжения с национальным правопорядком.

Подводя итог, исходя из позиции КС РФ следует, что он не ограничивает право на защиту в межгосударственном органе, что гарантированное гражданам право на судебную защиту посредством обращения в органы наднациональной юрисдикции, в том числе в рамках Конвенции о защите прав человека и основных свобод, предполагает обязанность государства проявлять максимум заботы об организации исполнения решений ЕСПЧ. Отступление от правовой обязательности постановлений 
Страсбургского суда допустимо лишь в исключительных случаях, когда их исполнение несовместимо с основополагающими установлениями Конституции РФ, что тем не менее не может служить преградой для изыскания совместными усилиями заинтересованных сторон, при активной роли Конституционного Суда РФ и ЕСПЧ, взаимоприемлемых способов минимизации конституционно-конвенционных коллизий. Таким образом, КС РФ призывает соблюдать принятые решения по ЕСПЧ, он только показывает алгоритм действий в случае правовой коллизии. Как в действительности будет применяться данный механизм и будет ли он злоупотреблять своими возможностями, или искать разумный компромисс в целях защиты права на обращение в межгосударственный орган за защитой своих прав, как КС РФ указывает в своей позиции по данному вопросу, покажет только время и практика.

$$
* * *
$$

1. Конституция Российской Федерации // Собрание законодательства РФ, 04.08.2014, N 31, ст. 4398.

2. О внесении изменений в Федеральный конституционный закон «О Конституционном Суде Российской Федераци»: федер. конст. закон от от 14.12.2015 N 7-ФКЗ // Собр. законодательства Рос. Федерации. 2015. № 51. Ст. 7229.

3. Герасименко Т.Ю.О новом механизме имплементации решений Европейского суда по правам человека в Российской Федерации/ Т.Ю. Герасименко// Современное право. 2016. №12. 111-113 с.

4. Какителашвили К.К. Решения ЕСПЧ и Конституционного суда РФ: Социально-правовой конфликт/К.К. Какителашвили // Законы России: опыт, анализ, практика. 2016. $72-75$ с.

5. Князев С.Д. Обязательность постановлений ЕСПЧ в правовой системе России (на основе практики Конституционного Суда Российской Федерации)/ С.Д. Князев//Журнал российского права. 2016. №12. 6-17 c.

6. Колосова Н.М. О конституционном праве каждого на международную судебную защиту в России./Н.М. Колосова//Журнал российского права.2012.№ 4 (184). 72-77.

7. Кузнецов Е.Н. Решения Европейского Суда по правам человека и новая практика Конституционного Суда России /Е.Н. Кузнецов// Арбитражный и гражданский процесс.2016. №.10.30-34 c.

8. По делу о проверке конституционности положений статьи 1 Федерального закона "О ратификации Конвенции о защите прав человека и основных свобод и Протоколов к ней", пунктов 1 и 2 статьи 32 Федерального закона "О международных договорах Российской Федерации", частей первой и четвертой статьи 11, пункта 4 части четвертой статьи 392 Гражданского процессуального кодекса Российской Федерации, частей 1 и 4 статьи 13, пункта 4 части 3 статьи 311 Арбитражного процессуального кодекса Российской Федерации, частей 1 и 4 статьи 15, пункта 4 части 1 статьи 350 Кодекса административного судопроизводства Российской Федерации и пункта 2 части четвертой статьи 413 Уголовно-процессуального кодекса Российской Федерации в связи с запросом группы депутатов Государственной Думы: Постановление Конституционного Суда Российской Федерации от 14 июля 2015 № 21-П //Собрание законодательства РФ.2015. №30.ст. 4658.

9. По делу о разрешении вопроса о возможности исполнения в соответствии с Конституцией Российской Федерации постановления Европейского Суда по правам человека от 31 июля 2014 года по делу "ОАО "Нефтяная компания "ЮКОС" против России" в связи с запросом Министерства юстиции Российской Федерации: Постановление Конституционного Суда Российской Федерации от 19 января 2017 № 1-П //Собрание законодательства РФ. 2017. N 5. Ст. 866.

10. По делу о разрешении вопроса о возможности исполнения в соответствии с Конституцией Российской Федерации постановления Европейского Суда по правам человека от 4 июля 2013 года по делу "Анчугов и Гладков против России" в связи с запросом Министерства юстиции Российской Федерации: Постановление Конституционного Суда Российской Федерации от 19 января 2017 № 1-П //Вестник Конституционного Суда РФ. 2016. № 5.

11. Филатова В. Пилотные постановления ЕСПЧ: Проблемы исполнения/ В. Филатова // ЭЖЮрист.2016. № 23.5 с.

12. Путин не исключил возможность выхода РФ из-под юрисдикции ЕСПЧ // Интерфакс, 14.08.2014 г. [Электронный ресурc] URL: http://www.interfax.ru/russia/391379 (дата обращения: 22.03.2017). 